DOi: $10.21554 / \mathrm{hrr} .042008$

\title{
PERSPECTIVES AND CHALLENGES OF INTERPROFESSIONAL WORK IN INSTITUTIONS FOR THE ELDERLY
}

Review article

\section{Sabira Gadžo-Šašić ${ }^{1}$ \\ IvanaRistić ${ }^{2}$}

Department of Social Work, Faculty of Political Sciences, University of Sarajevo, Bosnia and Herzegovina College of Social Work, Belgrade, Serbia

Received: 5/9/2019

Accepted: 2/12/2020

\begin{abstract}
The main characteristic of the $21^{\text {st }}$ century is the increase in the number of third-age persons in the total human population of the world. Therefore, it is an imperative to create new modes and to improve existing modes of assistance and support to this group of people. This paper specifically seeks to draw attention to possible directions for the development of care services for the elderly. The tasks of the professionals (social workers and occupational therapists), working in institutions for the permanent placement/accommodation and care of the elderly, were also analyzed. In addition to the above-mentioned, the status of the elderly population in Bosnia and Herzegovina and Serbia hasbeen reviewed.
\end{abstract}

Keywords: social work, occupational therapy, the elderly, institutions

\footnotetext{
${ }^{1}$ Correspondence to:

SabiraGadžo-Šašić, Assistant Professor, Department of Social Work, Faculty of Political Sciences, University of Sarajevo, Bosnia and Herzegovina

Skenderija 72, 71000 Sarajevo, Bosnia and Herzegovina

E-mail: sabira.gadzo.sasic@fpn.unsa.ba

${ }^{2}$ IvanaRistić, Assistant Professor, College of Social Work, Belgrade, Serbia

E-mail: ivana.ristic@asp.edu.rs
} 


\section{INTRODUCTION}

The ever-increasing growth rate of the elderly population in the total population number of the world is certainly one of the most important features of the $20^{\text {th }}$ and especially the $21^{\text {st }}$ century. Such trend poses an increasingfor professionals, to create new measures and services that would enrich existing modalities to help this group of people. Considering the aforementioned, it is not surprising that the European Union (Active aging and solidarity between generations - statistical portrait of the European Union, 2012) has declaredthe year 2012, the Year of Active Aging and Intergenerational Solidarity. The EU set following objectives for that year: Raising awareness on the value of active aging, highlighting the contribution that older people can make to the society, the economy and in particular, mobilizing overall potential; exchange of ideas and good practices on how to promote active aging policies and solidarity between generations; to offer a framework for action to enable Member States and interested parties to develop policies and concrete activities to encourage active aging (Štambuk; Sučić, 2014).It can be stated that even today- seven years after the adoption- these objectives present a challenge. In order to create an environment that would provide an adequate framework for completing at least some of the objectives, all societies should be focused on creating measures, models and policies that should improve services for the elderly population, especially because the elderly are a group of socially excluded people, who have not acquired specially-prescribed rights such as children, women and persons with disabilities.

Therefore, despite predictions that by 2030 there will be one in four people over the age of 60 , this socially excluded group has not received particular public attention-with the aim of creating an environment conductive to greater social inclusion of elderly.

Nevertheless, many countries are currently reviewing their policies in light of the principle that elderly are a valuable and important component of a society. Demographic changes that are evident in the increasing proportion of the elderly population in the total population are widespread in Bosnia and Herzegovina, Serbia, as well as in the rest of the region. In Bosnia and Herzegovina, this is an issue that has been recognized in development documents since the first Development Strategy of Bosnia and Herzegovina, and it is still present in new development documents - including the Social Inclusion Strategy that has been adopted by the Federation of Bosnia and Herzegovina and the Brčko District. However, it is a devastating fact that the quality of life and well-being of the elderly population has not reached the required level. As for the situation in the Republic of Serbia, according to the Statistical Office of the Republic of Serbia in 2016, 7,058,322 inhabitants were registered, and the population aged 65 and over comprised 19\% of the total population. At that time, $57.5 \%$ of the elderly population were women. This information in itself speaks of the necessity of involving all structures in the creation of a support network for this group of people, which, in addition to being more numerous, is also becoming more excluded.

It can be concluded, that in creating new approaches to providing assistance to this group of inhabitants in the countries in the region, a special place should belong to the creation of innovative modalities for improving the quality of life and well-being of the elderly, especially those that are housed/accommodated in care institutions. Moreover, in societies where loneliness is increasingly perceived as the number one problem, an increasing number of thirdage persons can be expected to express a desire to be placed/accommodated in acare institution with the aim of overcoming problems - especially loneliness.

\section{Social work and occupational therapy with the elderly, with special reference to their importance in residential care institutions}

Although various definitions of social work as an academic discipline and practical social activity can be found in the professional literature, the starting point of all these definitions is the set of efforts put in by professionals to achieve greater social development, that is, the wellbeing of all people. 
When pursuingbetterwell-being for the elderly(especially in institutions for the permanent accommodation and care of such persons) the science of occupation is important. It focuses on research aimed at examining patterns and traits of purposeful and meaningful activities that people engage in throughout their lives, as well as their links to the health and progress of not only individuals, groups of people but also the entire community. It has the ultimate aim of improving the quality of life (Law et all, 2002; Zemke\& Clark, 1996). In this regard, the overlapping between the scientific fields of social work and occupational therapy implies the importance of quality of interprofessional collaborative work in practice.

Following all the above, on the one hand, social work practice is oriented towards meeting human needs and developing human resources (Gadžo-Šašić, 2019) (especially of marginal group), in which elderly undoubtedly have a special place. On the other hand, activities of occupational practices in the field of work with the elderly are oriented at assisting the elderly with the aim of training for independent living.

Of course, this begs the question of why in modern societies the elderly are so excluded from social processes, and why do they need the continued support of professionals (social workers, occupational therapists)? In seeking the right answer, we shouldnote that, unlike earlier social structures thatwere based on the rules of the so-calledgerontocracy(where the elderly werethecenter of attention and decisionmaking), in modern civilizations, younger people take on this role.On the one hand, such environment contributes to the growing prejudice of old age and aging as something that is negative and on the other, it leads to the idealization of "youth".

In addition, all modern societies share the fate of the negative demographic changes that are manifested by increasing the proportion of the elderly in the total population, primarily due to the prolonged life expectancy of the person as well as the decreased birth rate.According to the authors (Haverka; Despot Lučanin; Lučanin, 2000), this trend will culminate by 2030 , especially in developed societies. We also should not forget the ubiquitous trend of the so-called "atomization" of the family, which contributes to the deepening of the problems of the elderly who, due to this trend, are increasingly feeling lonely and left to themselves. The described social contextcontributes to the growing alienation of older members of the society, and topics that directly concern them become taboos. Thus, communication of third-age persons about everything that seems important to them (retirement, property, real estate, life support, loneliness, accommodation in an institution, seeking help in everyday life that is often very monotonous and troublesome) comes down to sporadic conversations with their peers, with little or no discussion of these topics in public. The reason for this is the fact that older people feel afraid that they will be accused of being selfish, but also because of the fear that they will experience inconvenience if they request humane treatments.In such an atmosphere, an environment is created in which social workers and occupational therapists are becoming expert figures, whichare increasingly challenged to find different solutions to overcome these problems.In fact, social workers as professionals should act as spokespersons for the problems and needs of the elderly. In this regard, they should advocate the rights and opportunities of the elderly, to inform the elderly of their rights, to work to create activities in local communities that aim at greater involvement of the elderly in everyday life. We can conclude that social workers and occupational therapists, through interprofessional collaborative work in practice, have an obligation to create activities that will enable third-age persons a quality life in their own home. This should be primarily implemented for the elderly who, despite a developed and open model of elderly care, are unable to live a decent life in their own household. The aforementioned professionals have to enable a quality and dignified life through the realization of different approaches in institutions that should be designed as institutions offering permanent or temporary accommodation for the elderly. 
In these institutions, professionals of social work and occupation therapy are particularly prominent professions, because the defined primary task of these professionals (social workers and occupational therapists) is to invest efforts that should make the elderly feel active and useful members of the society despite accommodation in an institution. Here, professionals face a particularly great challenge because they have a task to break the prejudices that prevail among these categories - that despite the developed opinion of social exclusion due to calendar age, accommodation in such an institution makes them even more excluded from social events. Due to the above, the literature cites several roles played by the social worker and occupational therapist in working with institutional care users. Some of these roles are: Providing information and encouraging care users to make choices and make independent decisions; assisting in the formation of care user councils; involvement of care users in decision-making processes and the formation of self-help groups (Štambuk; Sučić, 2014, according to KorenaDoron, 2005).The implementation of these measures is especially hampered by the fact that accommodation in an (elderly) institution is considered shameful, and younger family members run the risk of declaring themselves bad relatives. The misinterpretation of life in such institutions is the thing that makes working with elderly hard. This happens because among third-age persons there is a common opinion that a care institution is a place where they will die. This makes it difficult for professionals to create attitudes about institutional life as a place where the elderly can live harmoniously, socialize and spend quality time. All this contributes to the fact that continuous work with the elderly leads to the so-called "burn out syndrome". The constant struggle for the rights of the third-age persons as well as the continuous development of ideas that can contribute to improving the quality of life of those who are accommodated in an institution or who are forgotten in the community - this often reminds the professionals themselves of their own transience and makes them think about the possibility that they will find themselves in the same or a similar position. That is the primary reason for highlighting/advocating specialization in social work and occupational therapy with the elderly. Specialization in this field as an important challenge for the profession is increasingly emphasized today (Mali, 2013), although most curricula that educate social workers include the subject Social work with the elderly. This is imposed as an obligation due to the fact that, for most professionals who continue to work with third-age persons, it is necessary to provide additional, continuing education, which would be a form of empowerment and information on new trends in working with this group of people.Specialization includes the development of competencies for working with the elderly, as well as developing the ability to create campaigns aimed at raising public awareness of the needs and rights of the elderly and the social and individual consequences of violating these rights. These activities would also encourage the participation of the elderly in life of the local community and provide conditions where (by exercising their rights and acquiring new knowledge and skills) seniors would remain active participants in the community and would be recognized as an important resource of social change, wherever they live (in their own household or accommodated in institutions for the elderly).The primary goal of cooperation of experts in the field of work with the elderly population is to create a society in which all members of the community, in accordance with their capabilities, would contribute to social development. The role of social workers and occupational therapists is therefore particularly important because they are persons (professionals) with whom the care user continually meets and cooperates. They familiarize the care user with the lifestyle in the institution and accompany him/her during his/her life in the institution, but also when leaving the institution. The social worker assumes the role of a mediator, that is, the social worker adjusts the needs and requirements of the care users, family and institution (Štambuk, Sučić, Mali, 2010). 
The occupational therapist is involved in the aspect of assessing the needs and ways of performing the task and assessing the care user's living space and determining ways which can be better adapted to the care for the user's needs (Sadiković, Muftić, Bećirević, 2006; Švraka, Avdić, Hasanbegović-Anić, 2012). The methods used in the paper are based on a holistic and client-centered approach (Townsend, 1997).

On the other hand, the social work methods used in working with the elderly are generally traditional methods. The first commonly used method is social work with the individual, which involves working according to the needs and desires of care users, in order to monitor care users and solve their individual problems. It may include talking to care users or a family member to get to know the care users and the problems they encounter during their accommodation, to resolve the care users' personal problems, as well as conflicting situations they find themselves in. As stated in the professional literature (Dervišbegović, 2001), social work is not exhausted by providing individual assistance to the client. Providing individual assistance is just one method of solving many people's problems when they are not able to solve them themselves. Because of this, group social work is increasingly emerging as an irreplaceable method of working with groups where individuals live. Group work with care users includes work with larger or smaller groups of care users in order to improve and maintain correct interpersonal relationships among them. Finally, the third traditional method of social work used in working with third-age persons is community work. This method covers activities related to the implementation of specific campaigns on opportunities, abilities and services for the elderly in local communities. These activities aim to inform the public about the achievements of the elderly or the services offered to the elderly. In practice, a combination of these methods is advocated, which should contribute to the greater social inclusion of third-age persons, that is, to help the person accommodated in the institution to become acquainted with the new environment, to follow the course of adaptation, to assist him/her in solving conflicts and other crisis situations. Following the above, social work in institutions can be classified into professional social work with care users, providing assistance to care users through individual and group work with the aim of providing social and emotional support and safety to care users, keeping records and documentation related to beneficiaries. The areas of duty of social workers that represent fields of overlap with occupational therapist's work is the organization of occupational, cultural, entertaining and recreational activities of the care users. In institutions for permanent accommodation of the elderly, social workers are also engaged in the activities of admission that include work on drafting contracts, opening personal files and personal records of care users, registration in institution register, regulation of pensions, disability benefits, health care, identity cards and other documentation depending on the individual need of the care user. Social workers are also involved in: monitoring the health of the care users and other changes they are facing as well as changes in the price of services; monitoring of billing of services; working with clients; drafting correspondence and information regarding care users; making official notes when depositing and taking over cash at the box office; attending the distribution of money, taking over and depositing pensions, disability benefits and other funds to care users; organization of leisure time, or organization of occupational and recreational activities of care users. A special segment of work of social workers, as well as occupational therapists, with seniors in institutions, relates to work with demented care users (work with balloons and balls to activate psychomotor functions, work with educational dice, puzzles, memo cards, with the aim of improving cognitive processes and motor skills). There is also work on keeping all records related to the provision of services in institutional and noninstitutional forms of protection, as well as the tasks and activities that need to be carried out after the death of the care user (making a death certificate, registering the death register, contacts with family, registrars); as well as work after the termination of the contract for the use of accommodation services in the institution. 
Based on the above mentioned, is not difficult to see the seriousness of the objectives and work that are placed before the social workers, working in the institutions for accommodation of the elderly. It is particularly important to emphasize that social workers and occupational therapists in institutions are not only limited to work within the institution they also develop a collaborative relationship with the wider community, which is the only way to achieve at least minimal openness of institutions to the life in the communities in which they are located.

\section{Traditional vs modern models of elderly care}

In the scientific literature, two traditional models of social and health care of the elderly are most often mentioned.The first model is an open model that defines the protection of third-age persons in their own home, which consists of a series of services that seek to preserve the independence and good psychophysical fitness of the elderly for as long as possible in order for them to remain independent for as long as possible. The main forms of this model of elderly care are: home services (housekeeping, food preparation, laundry, etc.), home delivery service, home care service, day care facility, entertainment, recreation and clubs for the elderly as a gathering place for fun, socializing, events, celebrations and the like.This model of elderly care also includes organized holidays for third-age persons with special care in the place of residence. It also includes an information service for informing the elderly about their rights, opportunities and best ways to use the service, as well as home medical care in cooperation with home care services, and senior support centers that provide courses that are useful for healthy living and for solving other specific problems of the elderly. The second model, the closed modelof elderly care, is implemented in special institutions for the elderly in which they are permanently or temporarily accommodated. The basic network of this kind of institutions includes:

-Homes for elderly providing permanent accommodation, nutrition, recreational activities, occupational activities and other activities.

- In addition to the above services, the gerontology center also provides home help services, day care and socializing. More specifically, gerontology centers are institutions that provide non-institutional care for the elderly in addition to institutional.

-Social-medical institutions for the care of third-age persons with severe psychophysical disabilities.

- Geriatric hospitals or wards in general hospitals are intended for the treatment of various diseases of the elderly. According to the standards of contemporary gerontology, which studies the legality of the aging process and problems related to the third age period, it is necessary to incorporate the approaches contained in the above traditional models of elderly care into one so-called "new" model that would give the elderly the care they need, according to their vitality and ability to perform daily activities. The primary objective of such a new approach to working with the elderly should be to improve the quality of life of third-age persons, regardless of whether they live in a rural or urban environment.In fact, models of care for the elderly should be designed to follow the trends of modern life. In the context of the elderly, social services include all social-protection rights such as: material security, allowance for care and assistance of another person, assistance at home, day care, placement with another family or social welfare institution.

In the creation and implementation of social services in modern societies, the key fact is that they should correspond to the level of development of a particular state, because the quality of all social services, and therefore those provided to the elderly, is influenced by the economic, socio-cultural and historical development of a certain society.

The logical question here is how to develop a costeffective and quality system of services for an increasing number of the elderly?

In searching for appropriate guidelines for finding the right answer, it is important to note that the increasing number of older people in the total human population brings certain obstacles, such as a lack of financial resources to achieve better quality services for the elderly. 
In this regard, professional literature (Havelka; Despot Lucanin, Lucanin, 2000) already points out that in the advancement of even basic models of protection of the elderly, a particular obstacle, which emerges as a constant of any social policy, is the permanent lack of funds. So, it seems right to point out that it is illusory to expect that, even through the continued economic and social development of the society, the disparity between the needs of the elderly and the ability to fulfill those needs will diminish. On the contrary, the opposite is more likely to happen.However,despite many obstacles, it is necessary to point out possible directions of development that should primarily contribute to the advancement of the quality of life and well-being of third-age persons. This is imposed as an imperative, primarily because social actors have a responsibility and duty to enable persons dignified life in the third age period, especially due to the fact that they are the persons who have borne the burden of the society development during their working life. So, for existing care services to be effective, it is necessary to know how people's needs change with aging. Numerous studies conducted in the Balkans have shown a fairly similar picture of the position of the elderly.It is also well known that more than $80 \%$ of those older than 65 suffer from a chronic illness, but fortunately there are very few severe illnesses. About a quarter of the elderly are restricted in their daily activities, while about $15 \%$ of the elderly are not able to perform the most important daily activities independently. This means that about $85 \%$ of the elderly are completely or mostly independent in their daily lives. About $6 \%$ of people over 65 and about $20 \%$ of people over 80 suffer from an organic mental illness. This means that in the elderly group, the majority of them have preserved mental abilities and mental health (Haverka, Despot Lucanin, Lucanin, 2000, according to: Schaie\& Willis, 1991; Perimutter\& Hall, 1992; Cox, 1993; Hayslip\&Panek, 1993; Hansen Lemme, 1995). It can be concluded that for the elderly housing/accommodation as a concept is much more than an elementary possession of a "roof over the head", that is, a certain residential area
(Koružnjak, 2003). For the elderly, it is a place of meeting other people, exchanging material and spiritual goods, accepting the rules of behavior within a certain group, forming their own "small world" etc. (Ajduković, 1995). It follows from the reasoning that age adjustment depends not only on biological and psychological factors but also on external ones, such as social environment, family circumstances, housing/accommodation conditions and support systems that exist in an environment and are aimed at assisting the elderly (Žganec, Rusac,Laklija: 2008, according to Bouillet, 2003).

Therefore, it can be stated that housing/ accommodation for the elderly does not only imply subsistence, but also everything that is incorporated into social inclusion, that is, the realization of social, economic and cultural rights (UNDP, 2007). Because of this, different types of housing/accommodation have been developed in the world. Given the level of dependency, there are numerous different types of residential care institutions for the elderly in the US. All types are classified into those with:

Low level of dependency (single-family housing/ accommodation), accommodation / apartments with additional activities / hobby, recreation etc./ (accessory apartments), small flats in basements of existing houses (granny flats),

Medium-low level of dependency (multistory/ multiunit building assemblies within an urban area, settlement or small town, so-called elderly housing multiunit, group homes, senior centers),

Medium level of dependency includes the widest range of housing/accommodation:

-Separated flats (domiciliary care facilities, board and care, personal care homes, independent congregate housing-retirement hotels) - Nursing homes, the so-called homes for the aged -Resorts or spas (rest homes)

-Health-related facilities

- Nursing homes for the elderly (seniors in last stages of illness), with the accommodation for their family members (hospices),

Medium-high level of dependency includes accommodation in nursing homes with various levels 
of care or clinics with ongoing and permanent care (continuing care retirement community) and

5. High levels of dependency that include polyclinic and intensive hospital monitoring (rehabilitation, acute-care hospitals) (Koružnjak, 2003).

European examples (Western Europe) also have different levels and models of care for the elderly and infirm. All of them, like the American, are also divided according to the needs and capabilities of third age person (Koružnjak, 2003, according to: Valins, 1988).

From the above mentioned, it follows that all models and services in the field of social protection should complement and meet the needs of third-age persons according to the principle of "least restrictive alternative". This principle implies that government interventions and / or services provided should be consistent with the capabilities and abilities of the individual to take care of $\mathrm{him} /$ herself. A prerequisite for achieving all of the above is the establishment of a quality network of interprofessional social and health care.

\section{Social exclusion of the elderly in Bosnia and Herzegovina and Serbia}

Continuous changes in the society, continually place new demands on individuals and groups, producing different positive or negative states in which these same individuals and groups may find themselves. In cases where social change leads to the creation of certain negative states for individuals or groups, then the term "socially excluded" is used for them, and the condition is referred to as "social exclusion". In Bosnia and Herzegovina, as well as neighboring Serbia, the elderly population is often considered highly vulnerable by different criteria. This is a group of people who are often marginalized in terms of their social influence, they are economically weaker than young people. They are also in stages of health risks, etc. All of this contributes to the weakening of the relationship between them and society, which makes them socially excluded members of the community. As it is pointed out in the professional literature (Žganec N., Rusac S., Laklija M., 2008), the key problem of the elderly is related to their social exclusion. The phenomenon of social exclusion of the elderly most often includes: the dimension of social relations that is usually weaker than in working and mature age, participation in cultural activities, access to services in the local community, exclusion from the neighborhood, access to redistribution of financial and other material goods (Walker and et al., 2006). The same authors (Žganec N., Rusac S., Laklija M., according to Walker et al., 2006) point out that the generation of baby boomers (people born between 1945 and 1965) is less attached to their community than earlier generations, and are therefore at greater risk of becoming socially excluded. Their social network is poorer in quality and quantity, so social contacts are superficial and they show less interest and need for belonging to the neighborhood.

All these problems are particularly present in the countries of the Western Balkans (Serbia, Bosnia and Herzegovina, Montenegro, Northern Macedonia, and Albania). It should be noted here that few measures are implemented in Bosnia and Herzegovina aimed at real involvement of the most marginalized groups. Within the set of social care institutions dealing with the provision of services and care for the elderly in Bosnia and Herzegovina, centers for social work are particularly distinguished. That is kind of institution which in addition to coordinated activities with a network of institutions at the level of the local community, especially in the field of health care and other governmental and non-governmental organizations sectors, also have specific statutory obligations to implement social protection measures for this group of the socially excluded. The entity laws (Law on the Basics of Social Protection, Protection of Civilian Victims of War and Protection of Families with Children of the Federation of Bosnia and Herzegovina, Article 12; the Law on Social Protection of RepublikaSrpska, Article 10; and the Law on Social Protection of District Brcko, Article 18) recognize the elderly without family care as a specific category of social care beneficiaries (persons over 65 (male) or 60 (female), who do not have family members or relatives who are legally required to support them, or that those family members are unable to fulfill the obligation of support). 
The law also stipulates that the elderly as well as other beneficiaries of social care (persons with disabilities and persons with physical and mental disabilities, financially uninsured and incapacitated persons, persons with socially negative behavior, persons and families in need of social care due to special circumstances) can exercise the following rights through Care Centers: the right for financial assistance, accommodation in other homes (elderly people who are unable to take care of themselves, and due to housing/accommodation and family circumstances are not able to afford protection in another way), placement/accommodation in a social care institution, home care and home assistance and professional work services. The exercise of the aforementioned rights in the territory of Bosnia and Herzegovina is conditioned by the material capacities of the entities and the Brčko Districtand this is an example of a violation of basic human rights - the right of equal social security and social protection. This is compounded by the fact that certain legal solutions that are in the best interest of the elderly population (e.g. placement/accommodation in another home) are almost never put into practice. It can be concluded that the programs for the elderly in Bosnia and Herzegovina are incomplete and uncoordinated, which is reflected in the overall quality and wellbeing of this population.

Concerning the position of the elderly in Serbia, available data (Babović, et al., 2018) indicate that their position is relatively unfavorable and that they face numerous problems in achieving satisfactory living conditions. So, compared to the situation in EU countries, the elderly in Serbia live shorter and with poor quality of life. The most important document that prescribes services and care for the elderly in Serbia is the Law on Social Care / Protection. In addition to the mentioned law, the rights of the elderly population of the Republic of Serbia are regulated directly or indirectly by many other laws such as: Law on Pension and Disability; Law on Compulsory Social Security Contributions; Labor law; Law on Social Housing / Accommodation and Law on Health
Insurance. Speaking of social services prescribed by the Law on Social Care / Protection of Serbia, these services mainly include accommodation services, day care and home help. According to Article 41 of this Law, an individual over the age of 65 may be a beneficiary of social care/protection services if his/her safety, well-being and productivity are endangered due to age, illness, disability or similar risks. It is interesting to note that the number of licensed nursing homes for social care and accommodation in Serbia is increasing. According to the reports of the Institute for Social Care / Protection at the Work of Private and Public Institutions for Accommodation (Republican Institute for Social Care / Protection, 2017a, 2017b) in 2016, there were 160 such institutions, of which 119 were private and 41 were public. In early 2018, the total number of active licensed nursing homes for social care and accommodation was over 190 . The trend of the construction of private nursing homes for the elderly is also present in Bosnia and Herzegovina. A special problem in Bosnia and Herzegovina is the fact that there are no specified standards for the establishment of such institutions. In future that can be a reason of why their uncontrolled increase could emerge. Even flats and abandoned houses are being used for this purpose (https://www.blic.rs/vesti/republika-srpska/ privatni-staracki-domovi-van-kontrole/qn0y3el). All of the above indicates that key social actors, both in Bosnia and Herzegovina and in Serbia, are doing little to realize activities that should contribute to a better quality of life and well-being for the elderly.

So, in the future, much more effort is needed to create the environment in which third-age persons would have quality access to key resources that enable them to achieve adequate involvement in various aspects of social life, as well as meet economic, social and cultural needs. It is crucial to point out that in addition to housing/accommodation, which defines the elementary living conditions, access to new communication technologies, especially IT, is important for the elderly. This is important for the elderly because the lack of information in this segment makes the elderly even more excluded. 
The reason for this lies in the rapid technical and technological development when access to information, funds or administrative services (issuance of personal documents, permits, regulation of tax obligations, etc.) is often achieved through various information and electronic portals and applications. This lack of information about these changes certainly contributes to the growing gap between society and elderly. Access to public transportation is also important, because it provides the spatial mobility necessary for an active life and connection with others in the community, regardless of whether the person is housed/accommodated in his/her own house or institution. Some authors have pointed out (Babovići et al., 2018) that this aspect has notbeen given adequate attention from the researchers to date.

\section{CONCLUSION}

Despite the continued emphasis on the problem, but also the need to create measures and policies aimed at improving the quality of life and well-being of the third-age population, it is more than obvious that these individuals are lonelier and excluded from the communities in which they live. This trend is especially dominant in the first decades of the $21 \mathrm{st}$ century. In order to overcome the negative trend of population aging, it is important to develop new and high-quality approaches to social services as key resources needed to provide better health and social care in the third-age life period.It is also necessary to focus on creating support networks for the elderly and to focus on enhancing the closed model of protection and care for this population. The objective of all forms of support and assistance should be aimed at creating an environment in which the elderly should not be seen as passive beneficiaries of services but as a social resource that needs to be activated and channeled into opportunities and potentials, and also motivated to contribute to community development. Certainly, the professions of social worker and occupational therapist play an increasingly important role in achieving this goal. The specificity of professional work with the elderly is especially evident in the institutions for the elderly. Some authors (Milosavljević, 1995) point out that the first objective of social work in institutions is discovering and stimulating the optimal life potentials of every social care institution beneficiary. The second objective that the same author points out is an effort to create optimal living conditions in the care institution to the general satisfaction of all beneficiaries. The third objective is helping the elderly to overcome the difficulties of life conditioned by living in the social care institution.

Occupational therapy, which includes meaningful activities that people engage in during their lives and which in the context of the elderly should contribute to the preservation of the existing, but also to the acquisition of additional vitality, also has an important place in modern care institutions for the elderly. It is important for the care institutions to classify daily activities into three groups: productivity, self-care, and leisure (Ristic, 2018). In the opinion of the same author, occupation should cover all aspects of the active process of living, which is especially important for persons after the age of 60 and 65, when the relationship between the individual and social roles drastically weakens. Following on from the above, the aim of social workers, as well as other professionals, through interprofessional collaborative work in practice, should be to improve the quality of life and well-being of third-age persons in care institutions and beyond.The above mentioned is particularly important because the social status of that group is not a personal problem for themselves (the elderly). It can be concluded that this isa serious social, legal and cultural problem that requires the involvement of many social actors. 


\section{REFERENCES}

Ajduković, M. (1995).Starost i starenje [Age and aging].IN: Društvenaskrb o starijimosobama: izazov 21.stoljeća. Zbornikradova: Makarska.97.

Babović, M. et al. (2018).Socijalnauključenoststarijihosoba u Srbiji [Social inclusion of elderly in Serbia].Beograd: CrvenikrstSrbije.

Bouillet, D. (2003). Mogućnostiizvaninstitucionalnihoblikaskr bi o starijimosobama [Opportunities for non-institutional forms of care for the elderly].Revijazasocijalnupolitiku. 10(3):321-333

Cox,H. G. (1993).Later life: the realities of aging. Englewood Cliffs: Prentice Hall.

Dervišbegović, M. (2001).Socijalni rad: teorijaipraksa [Social work: theory and practice]. Sarajevo: Zonex.

European Commission (2012).Active aging andsolidarity between generations - statisticalportrait of the European Union 2012

Gadžo-Šašić, S.(2019).Socijalni rad i socijalnirazvoj: izazovii mogućnosti u prvimdecenijama 21. vijeka[Social work and social development: challenges and opportunities in the first decades of the 21st century].DHS - Društvene $i$ humanističkestudije, Filozofskifakultet u Tuzli, 1(7), 387-400.

Havelka, M., Despot Lučanin, J., \&Lučanin, D. (2000). trebestarijihosobazacjelovitimuslugamaskrbi lokalnojzajednici [Elderly people's needs for comprehensive care services in the local community].Revijasocijalnepolitike. 1.19-27. Zagreb.

Hansen Lemme, B. (1995).Development in adulthood.Boston: Allyn and Bacon.

Hayslip, B., \&Panek, P. E. (1993).Adult developmentand aging. New York: Harper Collins.

http://nasedoba.me/aktuelno/polozaj-starijih-osoba-u-drustvu/ http://www.gcs.com.ba/socijalni\%20rad.html

https://www.blic.rs/vesti/republika-srpska/privatni-starackidomovi-van-kontrole/qn0y3el

Koružnjak, B. (2003).Stanovanjezastarijeinterdisciplinarnipristup $\mathrm{u}$ formiranjuopćegmodelast anovanjazastarijeosobe [Housing for the elderly - an interdisciplinary approach to the development of a general model of housing for the elderly].Prostor, 1[25] 11[2003] 1-10.Arhitektonskifakultet, Sveučilište u Zagrebu.

Koren, C., \&Doron, I. (2005).Being a social worker in homes for the aged: The real, the ideal, and the gaps between.Journal of Gerontological Social Work, 44(3-4), 95-114. doi:10.1300/ J083v44n03_07.

Law, M., Polatajko, H., Baptiste, S. \& Townsend, E. (2002).Core Concepts in Occupational Therapy.u: Townsend, E. (ur.). (2002). Enabling Occupation: An Occupational Therapy Perspective.Ottawa.CAOT.29-56.
Mali, J. (2010).Social work in the development of institutional care for older people in Slovenia.European Journal of Social Work, 13(4), 545-559.doi: 10.1080/13691450903403784.

Mali, J. (2013). Socialnodelo s starimiljudmikotspecializacija stroke [Social work with the elderly as a specialization of the profession].Socialnodelo,52(1).57-67.

Milovanović, M. (1995).Socijalni rad u ustanovamasocijalnezaštite [Social work in social care institutions].Beograd: Udruženjestručnihradnikasocijalnez aštite, SavezdruštvasocijalnihradnikaRepublikeSrbije.

Perlmutter, M, \&Hall, E. (1992).Adult development and aging. New York: John Wiley and Sons.

Pimunović, D. (2004). Radnaterapija u gerijatriji [Occupational therapy in geriatrics]. Ljetopisstudijskogcentrasocijanograda, 11(2),289-299. Zagreb:Pravnifakultet.

Republičkizavodzasocijalnuzaštitu (2017a).Izveštaj o radulice nciranihustanovazasmeštajodraslih $i$ starijihkorisnika $u$ 2016.godini [Report on the work of licensed residential care facilities for adults and seniors in 2016].Beograd.

Republičkizavodzasocijalnuzaštitu (2017b).Izveštaj o raduustanovazasmeštajodraslih $i$ starijihkorisnika $u$ javnomsektoruza 2016.godinu [Report on the work of institutions for the placement of adults and elderly users in the public sector for 2016].Beograd.

Ristić, I. (2018). Štasuokupacije?Smisaoiznačaj [What are Occupations? Meaning and significance]. PARADIGMA: Časopiszateoriju i praksusocijalnograda, specijalneedukacije $i$ rehabilitacije 1, 67-76.Beograd: Visokaškolasocijanograda.

Sadiković, S., Muftić M., \&Bećirević E. (2006). Okupacionaterapija u rehabilitaciji [Occupational therapy in rehabilitation].Sarajevo.

Schaie,K., W.,\&Willis,S.L.(1991).Adult developmentand aging. New York: Harper Collins.

Štambuk, A., Sučić, M., \&Vrh,S. (2013). Socijalni rad u domuzastarije i nemoćneosobe-izazoviipoteškoće [Social work in a nursing home - challenges and difficulties]. Revijasocijalnepolitike, 2.185-200. Zagreb.

UNDP (2007).Socijalnauključenost [Social unclusion].Izvještaj o humanomrazvoju.

Švraka, E., Avdić, D., \&Hasanbegović-Anić, E. (2012). Okupacionaterapija [Occupational therapy]. Fakultetzdravstvenihstudija u Sarajevu.Univerzitet $u$ Sarajevu.

Valins, M. (1988).Housing for Elderly People.London: The Architectural Press.

Walker, A., Barnes, M., Cox, L., \&Lessof, C. (2006).New horizons research programme. Social exclusion of older people: Future trends and policies.Think piece.London: Department for Communities and Local Government. 
Zakon o socijalnojzaštiti (2011).Službeniglasnik RS broj 24/11.

Zakon o socijalnojzaštitiBrčkoDistrikta (2002).Službeniglasnik BrkoDistriktaBiHbroj1/00.

Zakon o osnovamasocijalnezaštite, zaštitecivilnihžrtava rata $\mathrm{i}$ zaštiteporodicesadjecom (1999). Sl. list FBiHbroj 36/99.

Zemke, R. \& Clark, F.(1996).Occupational Science: The evolving discipline. Philadelphia: FA Davis Company.

Žganac, N.,Rusec, S., \&Laklija, M. (2007).Trendovi u skrbizaosobestariježivotnedobi u RepubliciHrvatskoji $\mathrm{u}$ zemljamaEvropskeUnije [Trends in the care of the elderly in the Republic of Croatia and in the countries of the European Union].Revijasocijalnepolitike, 2, 171-188. Zagreb. 